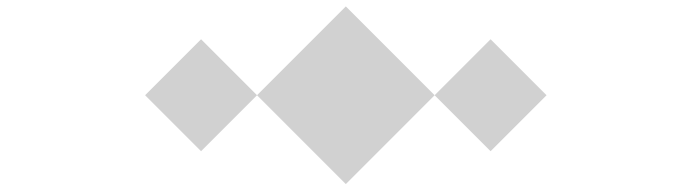

光で脳を制御する！?

大阪バイオサイエンス研究所神経科学部門 現在の所属: *関西医科大学解剖学第 1 講座 片岡洋祐

\section{1.はじめに}

脳はいかにして膨大な量の情報を処理しているの か? 脳が喜びや苦しみを感じるとはどういうことな のか? 個々の神経機能から意識の奥深いところへと 今日の科学は迫りつつある.ヒトや動物の脳のはたらら きを体に傷をつけることなくの艺き見ることができる 非侵襲的脳機能イメージング法の開発もこれに大きく 貢献してきた.とりわけPET (陽電子放射断層撮影法) やfMRI (機能的磁気共鳴画像法) は脳内での神経活動 に伴う代謝ダイナミクスを2次元あるいは3 次元的に 描出することを可能にし, 近年ますます注目されてい る.ところが一方, 実際の我々の脳の中では各機能領域 の間に神経ネットワークがはり巡らされ, 情報処理が さまざまな領域で同時に進行しているため, これらの イメージング技術は関係領域を一挙に描出してくれる ものの, イメージングのみでは各微小領域の役割や機 能的つながりを詳細に理解することは難しいといった 一面がある. まして臨床医学においてはイメージング 技術は病気の診断には威力を発揮するが, 治療技術と しては使えない, 乥こで, 脳内の各領域の神経活動や領 域間の神経ネットワークを1つ1つ体外から可逆的に 活性化したり抑制する技術の開発が必要となってくる のだ.

では, 脳機能を体外から可逆的に制御するにはどん な方法が考えられるだろう. 古くから脳機能の研究の ためにさまざまな薬物か開発され, 脳局所に直接注入 する実験が多く行われてきた.しかし, 投与した薬物が 脳組織の中で広がるのに時間がかかるため, 薬物の作
用領域や作用開始時間がはっきりしないといった問題 がある.また, 薬物を脳内の目的領域へ直接投与するわ けだから臨床治療技術としては生体への侵襲が大き い. 近年, 体外からの磁気刺激で脳表面の神経を刺激す る方法か開発された 囲を細かく選択することができず2), 研究によく利用さ れるげっ歯類などの小さな脳への使用は難しい. しか も, 弚の対象領域は脳表面に限られる.では, 光はどう か? 光なら生体をある程度透過するから, 脳組織を できるだけ傷つけずに目的組織まて到達させることが できる.しかも，照射領域を絞ったり広げたり，あるい は任意の形に設定することも容易であろう．しかし，は たして光照射で神経機能を可逆的に制御することなど 可能なのか?

\section{2 . 光酸化法による神経伝達抑制}

1 つのアイデアとして, 光エネルギーを神経組織へ効 率よく作用させる媒体の利用が考えられる. 例えば光 増感色素が光れだ. 我々の身の回りにあるいくつかの 色素は特定の波長の光を吸収すると大量の活性酸素種 (おもに一重項酸素) を生成する゙'.こういった一群の 色素を光増感色素とよぶ. 生成された一重項酸素は化 学的に大变不安定で, 短時間のうちに周囲組織の脂質 やタンパク質と反応し, これらを酸化してしまう(光 酸化反応, 図 $1 \mathrm{a})$. 通常, 我々の生体では,さまざまな生 理機構か江妙にはたらいて組織のレドックス(酸化還 元) 状態を調節し, 生体内分子を正常に機能させてい る.もし中枢神経組織を急激に酸化して膜脂質やタン パク質などの機能分子のはたらきを修飾すれば, 結果 として神経伝達機能を修飾あるいは低下させることが できるのではないか?

事実, この光酸化による神経伝達抑制現象をラット 海馬スライス標本を用いて確認することができる. 微 小タングステン電極でスライス標本中の神経線維を刺 激し, さらに微小ガラス電極を乥の近傍へ刺入して刺 激した神経線維の電気的興奮やシナプス後電位を細胞 外記録する. 光して, 暗中にて細胞外液に光増感色素を 添加するわけであるが, このとき光増感色素の選択が 実験成功へのポイントとなる. 重要なことは, 暗条件下 と明条件下での励起効率の差が極端に大きいもの,つ まり暗中ではほとんど組織酸化を引き起こさず,ひと

\title{
Photo-Dynamic Manipulation of the Brain
}

Yosky KATAOKA

Department of Neuroscience, Osaka Bioscience Institute

*Present address: Department of Anatomy and Cell Science, Kansai Medical University 
たび光を照射すると急激に組織を酸化するものを選択 することである.ここでは光増感色素としてローズベ ンガルを用いた. 暗中にて $3 \mu \mathrm{M}$ のローズベンガルを細 胞外液と一緒に 10 分間灌流し, 光の後, 細胞外液中か ら余分なローズベンガルを5 分間洗い流す. 光して, い よいよ光照射. スリットを自作すればスライス組織上 に好みの照射領域を設定できる. 照射用の光源は使用 する光増感色素の吸収波長を含むものであればよい. ローズベンガルの吸収波長は580 nm 付近にあるため, 顕微鏡のハロゲン光源を用いてもよい. 図 $1 \mathrm{~b}$ は顕微鏡 光源 (赤外波長はカットされたハロゲン光) を用いて 照射出力 $50 \mathrm{~mW} / \mathrm{cm}^{2}$ (脳スライス上での強度) で20秒 あるいは30秒間照射した場合の興奮性シナプス伝達効 率の変化を示したものである. 光照射時間によく相関 してシナプス伝達が抑制され, さらに照射後数十分か けて徐々に回復することがわかる．もちろん強すぎる 組織酸化は細胞死を誘導する. 実験対象や目的に応じ て光増感色素の濃度, 光照射強度および照射時間を適
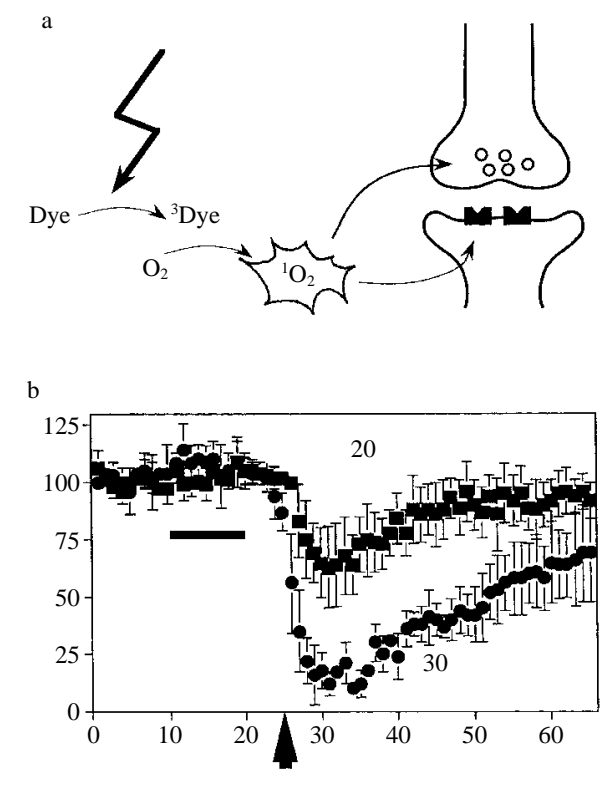

図1 光酸化法の概略と興奮性シナプス伝達抑制効果

(a) 光を吸収して3重項励起状態となった光増感色素か ら酸素分子にエネルギー移転が起こって一重項酸素分子 が生成される. 生成された一重項酸素分子は周辺分子と 反応して組織を酸化する.酸化された神経組織ではシナ プス伝達が抑制される. (b) ラット海馬スライス標本か ら記録した興舊性シナプス後電位を光酸化前を基準に相 対值としてブロットした (20秒照射 5 検体および 30 秒照 射 7 検体の方れ艺れの平均值と標準偏差)。(文献 4 より， 一部修正)
切に設定することがポイントである.ここで興味深い のは, 光酸化強度をある範囲て設定すれば, 神経の軸索 伝達機能 (活動電位の伝播) にはほとんど影響を与え ず, シナプス伝達機能のみを選択的に抑制できること である.この事実はシナプス伝達機能か組織酸化に対 してとりわけ脆弱であることを示しているのかもしれ ない.

さて, 次にこの光酸化技術を自由行動下の動物の脳 に応用してみよう. ハロセン麻酔下のスナネズミの脳 内, 特に行動制御にかかわっている線条体 (右側背側 線条体) へ $1 \mathrm{mM}$ のローズベンガルを $1 \mu \mathrm{l}$, 細いガラス
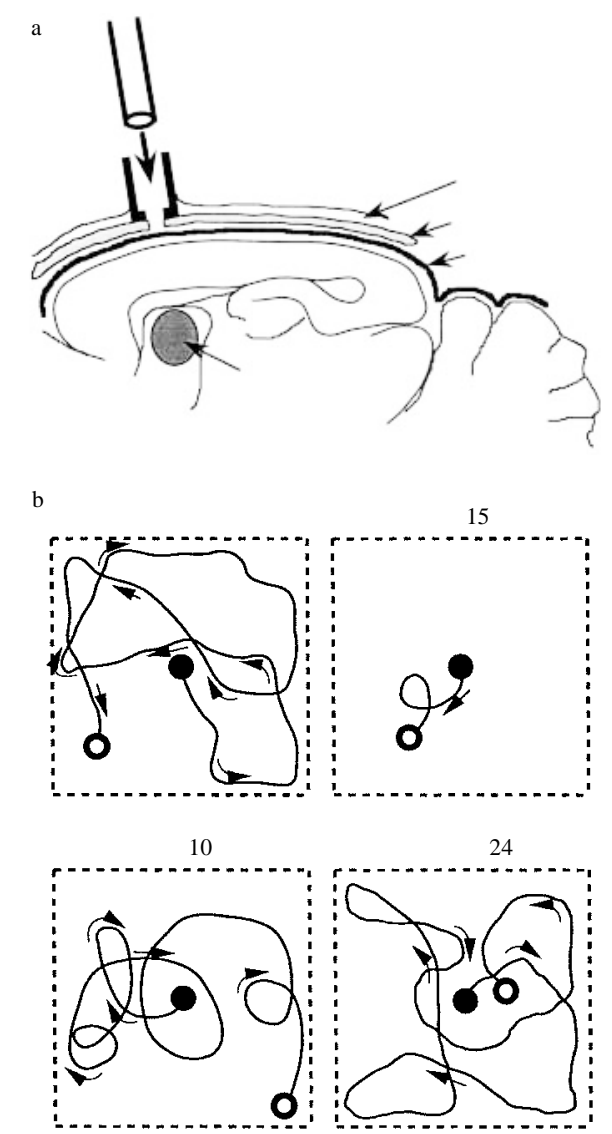

図2 自由行動下のスナネズミ右側背側線条体への光酸化実験 の概略と行動変化

(a) 光ファイバー挿入用ソケットを頭蓋骨に装着し, 1.4 $\mathrm{mm}$ 径の光ファイバーを用いて自由行動下のスナネズミ 脳内光増感色素投与部位を硬膜の外から光照射した。

(b) 光酸化前後におけるフィールド内 $(80 \mathrm{~cm} \times 80 \mathrm{~cm})$ でのスナネズミの1分間の行動軌跡 (ニューロサイエン ス社製ビデオイメージモーションアナライザーを使用し て記録・解析した). 黑丸が動物行動のスタート地点で白 丸が1 分後の位置. (文献4より, 一部修正) 
管 (先端径約 $50 \mu \mathrm{m})$ を用いてゆっくりと注入する.ロ ーズベンガル投与用のガラス管刺入に際して, 頭蓋骨 に小さな穴 (直径 1 〜 $2 \mathrm{~mm}$ ) を開ける必要があるが, 兴の上に光ファイバー装着用のプラスチックソケット を固定し, 動物が動き回っても脳表面からの照射光が 色素注入部位に安定して照射されるよう準備しておく (図2 a). 薄暗い部屋で動物を十分麻酔から覚まし, 実 験を開始する. 光ファイバーをソケットに扦入し, 動物 行動をビデオ装置て録画しながらハロゲン光 (赤外波 長は含まない) を脳の外から照射した. 脳深部では照 射光がかり減弱するため, 脳表面上での照射出力を $120 \mathrm{~mW} / \mathrm{cm}^{2}$ とスライス実験に比べて少し強めに設定 した. 产のときの動物行動の変化を図 $2 \mathrm{~b}$ に示す. 光酸 化によって背側線条体の神経伝達を中程度に抑制する と, 動物は酸化側へのみ回転するようになる. 产の後, さらに酸化程度を増すと, 動物の自発運動量が減少し, ついは自発運動が消失する.この行動変化も脳スラ イス実験で観察した神経伝達抑制と同樣に可逆的であ り, 数時間から 1 晚のうちに完全に回復する. こうした 実験をとおして, 脳内のさまざまな領域がどういった はたらきを担当しているのかを明らかにしていくこと ができる.

以上, 生体組織への光作用を光増感色素を用いて増 幅すれば, 脳内の神経活動をある程度制御できること を述べた.詳細は文献4を参考にしていただきたい. 今 後, 本法はさまざまな光増感色素の選択・開発により, さらに特異的な神経活動制御が可能となることが予想 され, 将来的にも光の応用に大きな広がりをもつもの と思われる. しかし, 光増感色素の投与は組織に侵襲を 与えることでもあり, 神経疾患の治療など, 臨床医学人 の応用は難しい. はたして光照射だけで脳機能を制御 することは不可能なのか?

\section{3 ・レーザー照射法による神経伝達抑制}

近年, 医療の現場では「レーザー治療」などといっ た言葉か聞かれる.もちろん対象は脳ではなく, 皮膚や 筋肉などの末梢組織であるし, また, 弚の言葉にはレー ザー光のもつ大きなエネルギーを利用して生体組織を 焼き切ってしまうような行為も含まれている.ただ, 光 の一部に「レーザーで痛みをコントロールする」とい つた意味合いの治療も実際に存在するのだ.もちろん 光増感色素を用いずに.いや, これが意外と効果がある らしい. 当初, 組織温度の上昇のせいであるとか, 血流 改善のせいだとか, 弚の効果についての見解はまちま ちであった・ところが最近になって末梢神経活動にレ 一ザー光が直接影響しているのではという報告もされ
始めている5). 我々がめざすものは, 生体へのダメージ をできる限り抑えた可逆的な脳機能コントロールであ る. はたして可能か？レーザー光を用いて挑戦して みた。

まずは手始めに光酸化実験同樣, ラット海馬スライ ス標本から電気刺激で誘発される興奮性シナプス後電 位を記録した. そとて, 神経刺激部位と記録部位を含む 領域に組織透過性のよい波長 $830 \mathrm{~nm}$ の近赤外レーザ 一光を組織温度への影響の少ない低出力て照射してみ た.すると,組織上での出力が $0.1 \mathrm{~W} / \mathrm{cm}^{2}$ を過ぎたあた りから, 光酸化ほど鋭敏ではないにしても神経伝達を 抑制する効果か観察されはじめたのだ. $1 \sim 4.8 \mathrm{~W} / \mathrm{cm}^{2}$ の出力範囲では照射開始後数分したあたりから一過性 の神経興奮度の上昇の後, 抑制効果か現れ, 照射開始 10 分程度で抑制効果が最大となった。 また, 照射を止 めると徐々に神経伝達は回復した. 次に麻斩下のげっ 歯類脳内大脳皮質や海馬を対象に, 頭蓋骨に開けた小 さな穴を通して脳の外からレーザーを照射してみたと ころ,やはり同樣の神経伝達抑制効果が確認された (図3).

なぜ,レーザー光が神経伝達を抑制したのか？ 今 のところ明確な答えはない. しかし, 現在さまざまな方 向から, 谷のメカニズムに迫りつつある. まず, 組織温 度への影響はどうか? 中枢神経伝達速度が組織温度 に鋭敏に影響を受ける点に注目し, 本レーザー照射に よる組織温度上昇程度を見積もってみた。光の結果, こ
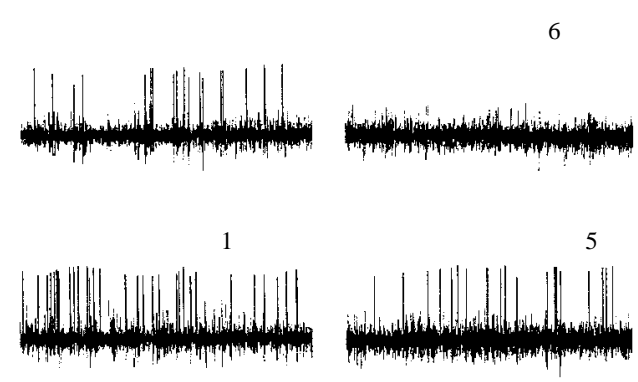

レーザー照射4分

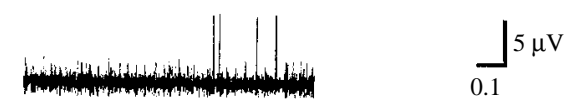

図3近赤外レーザー照射によるスナネズミ大脳皮質神経活動 抑制効果

麻酔下 (ウレタン $1.0 \sim 1.2 \mathrm{~g} / \mathrm{kg}$ 体重) スナネズミ大脳皮 質 (一次聴觉野) における自発神経活動を記録し, 硬膜の 外から記録部位をレーザー照射した.レーザーによる神 経活動抑制に先んじて, 照射開始1 分前後に一過性の活動 增強がみられた。 
こで用いた照射出力範囲であればたかだか $1 \sim 2{ }^{\circ} \mathrm{Cま}$ でであると思われ，組織温度上昇による神経伝達抑制 効果であるとは考えにくいという結論を得た . 次に光 酸化効果はどうか? 生体にも微量ではあるが光増感 効果をもった内在性色素が存在する可能性がある. 它 こで, 組織中のタンパク質や糖, 脂質を酸化すると形成 されるアルデヒドをシッフ試薬を用いて組織化学的に 描出し, 組織の酸化程度をレーザー照射前後で調べて みた。しかし, 前述した光酸化実験と比較して, 神経抑 制を期待できる程の組織酸化所見は得られなかった。

最近, 著者らはパッチクランプ法を用いて海馬培養 神経細胞の静止膜電位を観察しながらレーザー照射 し,レーザー照射が膜電位を過分極させ, 同時に膜抵抗 を減少させることを見いだした.これらの事実は,レー ザー照射が活動電位の発生効率を下げ,さらにシナブ ス伝達効率をも低下させることによって神経活動を抑 制していることを示唆している.しかし, いかなる分子 メカニズムを介して神経細胞膜へのレーザー効果が発 揮されているのかは, 今もって謎のままである.また， 電気生理学以外の実験・検討においても,レーザー照 射が神経伝達機能のみならず,細胞内ATP/ADP代謝や 脳血流など, 脳代謝をも制御する可能性が見いだされ つつある. 今後, てんかんや精神外傷, 虚血性神経障害, 神経脱落疾患など, さまざまな中枢神経疾患治療へも 応用されうるものと期待され, 生体へのより侵襲の少 ない照射法の開発や安全基準を含めた照射ガイドライ ンの整備も必要となってくるであろう. 基礎研究, 臨床 応用の両面において, ますます興味のうくらむ分野で ある

\section{4.まとめ}

表1で光酸化法およびレーザー法による神経伝達抑 制技術を比較した.これら光エネルギーを用いた脳機 能制御技術は培養標本からスライス標本, in vivo 系ま ですべてに利用でき, 光照射野の設定, 光照射強度, 照 射時間など多くのパラメーターを調節することによっ
表 1 光酸化法とレーザー法による神経活動抑制の比較

\begin{tabular}{|c|c|c|}
\hline & 光酸化法 & レーザー法 \\
\hline $\begin{array}{l}\text { 光照射強度 } \\
\text { およひ時間 }\end{array}$ & $\begin{array}{l}1 \sim 120 \mathrm{~mW} / \mathrm{cm}^{2} \\
\text { 数秒〜数分 }\end{array}$ & $\begin{array}{l}1000 \sim 5000 \mathrm{~mW} / \mathrm{cm}^{2} \\
\text { 数分〜数十分 }\end{array}$ \\
\hline $\begin{array}{l}\text { 神経伝達 } \\
\text { 抑制樣式 }\end{array}$ & シナプス伝達効率低下 & $\begin{array}{l}\text { 活動電位発生効率および } \\
\text { シナブス伝達効率低下 }\end{array}$ \\
\hline $\begin{array}{l}\text { 神経伝達抑制 } \\
\text { メカニズム }\end{array}$ & 組織酸化 & $\begin{array}{l}\text { 細胞膜電位過分極 } \\
\text { おうよび膜抵抗低下? }\end{array}$ \\
\hline 組織侵襲性 & $\begin{array}{l}\text { 光増感色素投与および } \\
\text { 酸化による組織障害 }\end{array}$ & $\begin{array}{c}\text { ない } \\
\text { あるいは } \\
\text { 少ない }\end{array}$ \\
\hline
\end{tabular}

て研究目的に適した利用ができる. 今後, 光酸化法にお いては新たな光増感色素の開発が求められる.またレ 一ザー照射法においては光の作用メカニズムの解明 と, 治療あるいは研究目的に合わせた波長・出力の選 択が重要な課題である.

\section{謝 辞}

本研究の一部は井上科学振興財団および光科学技術 研究振興財団の助成と文部省科学研究費 (総合脳) に より遂行させていただいた.なお,レーザー照射におけ る神経伝達抑制実験は京都府立医科大学麻酔科学およ び生理学教室, 同志社大学工学部知識工学科との共同 研究によって行った.

\section{文 献}

1) Barker, A. T., Jalinous, R. and Freeston, I. L. (1985) Lancet 8437, 1106-1107.

2) Ruohonen, J. and Ilmoniemi, R. J. (1998) Med. Biol. Eng. Comput. 36, 297-301.

3) Martin, J. P. and Logsdon, N. (1987) Arch. Biochem. Biophys. 256, 39-49.

4) Kataoka, Y., Morii, H., Imamura, K., Cui, Y.L., Kobayashi, M. and Watanabe, Y. (2000) Eur. J. Neurosci. 12, 4417-4423.

5) Tsuchiya, K., Kawatani, M., Takeshige, C. and Matsumoto, I. (1994) Brain Res. Bull. 34, 369-374.
片岡洋祐 (かたおか ようすけ)

関西医科大学解剖学第 1 講座 (システム細胞科学) 連絡先: = 570-8506 大阪府守口市文園町 10-15 E-mail: kataokay@takii.kmu.ac.jp 